\title{
Continued spread of Zika raises many research questions, WHO says
}

\author{
Anne Gulland \\ London
}

The continued spread of the Zika virus to new countries means that it remains an international public health emergency, the Zika emergency committee of the World Health Organization has said.

Both Singapore and Guinea-Bissau reported their first cases in the past two months. Singapore first notified WHO of the presence of the virus at the end of August, ${ }^{1}$ and 115 cases were confirmed by 2 September. Guinea-Bissau has reported four cases of Zika and five cases of microcephaly, the congenital neurological condition that has been linked with the virus in Brazil. An epidemiological link between the Zika cases and the microcephaly in Guinea-Bissau has not been confirmed.

David Heymann, professor of infectious disease epidemiology at the London School of Hygiene and Tropical Medicine and chair of WHO's Zika emergency committee, told a press conference that, although scientists know much more about Zika than they did seven months ago when the global health emergency was first declared, there is still an "urgent need to continue sustained and global research."

"This extraordinary event is rapidly becoming, unfortunately, an ordinary event, and Zika is beginning to spread and continuing to cause outbreaks in many countries around the world," he said.

Heymann said that research was needed into whether any cofactors - such as genetic or nutritional factors, environmental contaminants, or coinfection with other diseases such as dengue - have led to the concentration of cases of microcephaly in the north east of Brazil, where $85 \%$ of cases have occurred. ${ }^{2}$ "There is a whole range of cofactors which must be eliminated if you are going to be able to say for sure, with certainty, that there is no cofactor. It's a very broad and complicated research matter, and this is the type of research that is going on in northern Brazil," he said.

Further research questions include the difference between the African and Asian strains of Zika and whether there is cross immunity between the two strains. The Asian strain has spread throughout the Americas and has been linked to microcephaly and other neurological conditions such as Guillain-Barré syndrome. In Guinea-Bissau the virology points to the strain being of African lineage, Peter Salama, executive director of WHO's health emergency programme, told the press conference. "So, the question becomes, does the African lineage cause the same kinds of neurological complications, whether it's microcephaly or Guillain-Barré syndrome, as those we've documented with the Asian lineage?" he said.

Scientists in Singapore are still looking at whether the cases there are caused by the Asian or African strain, Salama said.

The emergency committee said that no cases of Zika virus infection were reported among either participants or spectators during the Olympic Games in Brazil. Salama said that there was little additional risk of cases during the Paralympic Games, which are due to start on 7 September. "We're still very much in the low season for transmission of vector-borne diseases, especially those transmitted by this particular mosquito vector," he said.

Dyer O. Outbreak of Zika in Singapore sparks warnings in neighbouring countries. BMJ
2016;354:i4740. doi:10.1136/bmj.i4740 pmid:27581052.
Collucci C. Brazil to investigate if other factors act with Zika to cause congenital defects.
BMJ 2016;354:i4439. doi:10.1136/bmj.i4439 pmid:27515384.
Published by the BMJ Publishing Group Limited. For permission to use (where not already
granted under a licence) please go to http://group.bmj.com/group/rights-licensing/
permissions 